\section{Business model maturity in management theory and practice - defining from an expert perspective}

"In business you always build the future, and the past is the base from which you emerge"

$$
\text { Jan Kulczyk }
$$

\section{Introduction}

In the era of constant uncertainty and crisis situations, the concept of "maturity" defining "the state of being complete, perfect or ready" is becoming increasingly popular in strategic management. The achievement of growing maturity by improving the relationship management processes should therefore be treated as a cyclic activity, which is, among others, focused on the continuous search for more effective and efficient business models that are adequate to the problems emerging in given conditions and the ones predicting these problems. When analysing the processes of implementing business models, it is noted that only mature models meet the requirements of the modern market. A mature business model devised as an introspective image of an organization, taking into account its environment, allows systematizing the process of strategic assessment of an enterprise and developing a direction for its operation. Referring to the issues outlined in this manner, in this paper the main dimensions implying its maturity were pointed out. 
Contemporaneity, characterised by the widespread changeability of various aspects of reality and the resulting cumulative complexity of relations between its components, on the one hand, causes the occurrence of a need to explain phenomena and their effects, and on the other, expedites the theory outdating process that would satisfy this need. This also triggers various discrepancies in the theory and practice expectations formed by management sciences. These dissonances concern, among others, the theories and practices in the field of strategic management. The accelerated process of some theories becoming obsolete caused by the variability of the conditions of their application also initiates difficulties in verifying their scientificity, and thus distinguishing between real and true concepts as well as methods from those on the market of fashion and quasi-scientific products. Another problem is the time dissonance between the expectations of practice and the offer of science in the form of indications and concepts for the functioning and development of the organisation in the conditions of postmodernity.

At this point, the authors postulate that the first step in establishing the theory of management and quality sciences should be the adoption of a new theoretical framework, where one could logically group together the statements that make up the theory of strategic management within an organisation. The author hopes that this research paper will, at least to a minimal extent, help to visualize the relations between theory and practice of management. Despite the fact that the issue is difficult, and it is not easy to propose any alternative positive solution to this issue, according to the author, a starting point for discussion - not a definitive position - should be offered.

Since many researchers and managers think about the essence, creation mechanisms and limits of the manufacturing model maturity, at this point, the author raises the fundamental question related to the issue: what dimensions (descriptions and desiderata) should be considered when conceptualizing the notion of a "mature business model"?

The formulated question became a starting point and a point of conducting a creative synthesis, based, on the one hand, on a detailed analysis of the problem theory, and on the other hand - on the research conducted so far by the author (Nogalski Niewiadomski and Szpitter, 2017; Nogalski and Niewiadomski, 2018; Nogalski Niewiadomski and Szpitter, 2018a, 2018b). The above question and belief related to the existence of economic demand for results of application nature were the main inspiration to undertake research whose main purpose is to recognize: how the mature business model is

Business model maturity in management theory and practice - defining from an expert perspective 
understood by selected experts related to the Polish agricultural machinery sector? In other words, it is about identifying what dimensions to consider when conceptualizing that idea? The achievement of the objective outlined in this way required the implementation of partial goals among which the following were distinguished:

- reconstruction and interpretation of the subject literature (embedding the problem in the theory of strategic management),

- defining the merits of the "business model" axiom (characteristics and etymology),

- discussion in a group of intentionally selected experts (compilation of dimensions reflecting a mature business model,

- compilation of the definition of a mature business model resulting from the literature exploration and research conducted among deliberately selected field experts.

In-depth studies in the area of the problem outlined above, own observations of economic practice and conducted empirical research conducted so far led to the formulation of specific questions, the solution of which was the answer to the main problem:

1. Do experts associated with the Polish agricultural machinery sector understand the maturity of the business model in a similar manner to selected science representatives (literature researchers)?

2. What descriptions reflect a mature business model?

3. Should, in the experts' view, mature business models be oriented on resources, product, customer and opportunity (agility, flexibility)?

4. Is it possible to use descriptions about the maturity of the business model using inventory recognition methods?

The formulated questions and belief on the existence of economic demand for results of application nature on the one hand were the main inspiration to undertake the research, while on the other, they became the starting point for formulating the below presumptions:

P1: The surveyed experts demonstrate a high level of domain knowledge and the ability to define selected categories in the field of management and quality sciences; adhering to all the rules of methodological rigour (including the selection of experts), there are premises for conducting research using heuristic methods.

P2: The definitions resulting from the expert discussion reflect distinctive descriptions for the business model, whose level of concretization indicates its maturity (research coincidence). 
P3: More and more companies organize a business model, in which the point of reference is an opportunity and the flexibility which implies the possibility of its realization.

P4: The process of transforming enterprises into a business model oriented at resources, product, customer and opportunity (agility, flexibility) shows their tendency towards maturity.

It seems that the complexity of problems and small, so far, scientific identification justify considering the mentioned issues as the research subject. Additional confirmation of the need to undertake research is also results from the fact that the literature on the subject usually refers to general definitions of the business model; there is a scarcity of studies presenting specific definitions specifying its maturity.

As new research directions in management and quality sciences are necessary to create more durable and effective business models, the presentation of the above issue was considered justified in this publication. The presented research do not exhaust the raised problems, but it is important that they at least should be a guide for those who want to make changes in their company. It seems that relatively small scientific recognition and complexity of problems occurring in business practice justify treating these issues as the subject of research, which is reflected in this publication.

\section{The business model as a basis for discourse about maturity - starting point}

In the opinion of the author of this development, in order to decide about the reality, phenomena and processes related to general management, it is necessary to clearly specify the scope of terms implied by the conducted research. As the business model term often appears both in common sense and in scientific studies, it was necessary to present selected definitions, compare them and confront them with reality. It allowed for the development, adoption and consistent use of the term, especially that its meaning is not precisely determined. The made attempts at terminological ordering in this study had only a cognitive value, which enabled the author to capture common areas, relationships and research approaches implying the possibility of recognizing dimensions of his maturity ${ }^{1}$.

1 The bibliographic knowledge accumulated for the purposes of this research includes the following two thematic resources (framework): Strategic management (business models) and Process and Project Management (organization maturity).

Business model maturity in management theory and practice - defining from an expert perspective 
Management and quality sciences belong to the knowledge disciplines that due to pragmatism and implementation - quite quickly try to take into account the changes that come about in the conditions that determine the development of companies, in the proposed solutions (methods, systems or concepts). The combinations of the emerging conditions, their dynamics, irregularity and transformations occurring in them create new challenges that must be met by reasonably and efficiently operating companies. The absorption of these changes takes place in the form of formulating and explaining not only paradigms, but also business models (Nogalski, Niewiadomski and Szpitter, 2017), the application issues of which should be a priority for scientific recognition, in the sphere of management science support for modern companies. In the current market conditions, the company management board and owners intending to increase the economic efficiency of the owned resources and implemented business processes should determine the way in which a company will create and provide the client with value and the approach to use to transform future revenues into profits. Attention is drawn to a way, optimal in a specific context of the organisation functioning, of creating value. The uniqueness aspect regarding the configuration of resources constituting the business model is emphasized in their definition by S. Ehiraj, I. Guler, H. Singh (2000). The authors believe that the configuration that consists of the objectives, strategies, processes, technology and structure of an organisation, creates value for clients, hence enabling an enterprise to efficiently compete within a specific market. The importance of business models can also be analysed in the context of company innovativeness. The business model in this case is perceived as the base for an innovative business concept. According to G. Hamel (2002), especially in the areas of the most modern sectors, new business models more disturb the old order than the implemented new technologies. They are often a novel concept of conducting a business. Indeed, using radical innovations, new market possibilities are often discovered. The approach to creating an innovation-based strategy was presented in a slightly different manner by W. Chan Kim and R. Mauborgne (2006). They suggest creating a competitive advantage by seeking a new market area, and capturing demand in it. This is possible thanks to such innovations that allow reducing the cost of products while increasing their value for customers.

The business model that allows organisation of information about a given product, enables the structuring of it as a whole and better describes the given implementation process. Thanks to this, models help in making decisions, i.e. they facilitate management decision and process. Owing to writing down and

$X X$

PRZEMYSŁAW NIEWIADOMSKI 
grouping information about a given process, business models facilitate the better understanding of it and manage it more effectively. The specific business model should clearly specify where the company takes the money from, what it sells, to whom it sells when it considers that it has achieved success. The enterprise business model can be treated as one of two (beside the environment) direct factors (determinants) affecting the effectiveness of the enterprise (Afuah and Tucci, 2003). The authors emphasize that these determinants, in turn, are influenced by the so-called change factor that indirectly, but significantly affects the efficiency of the enterprise. They believe that economic efficiency can be accurately defined based on such indicators as: profit in accounting terms, added economic value, market value of shares, return on sales, return on assets or return on capital. According to the adopted definition, a business model is a method that an organisation applies to increase and use resources to present customers with a product and service offer whose value exceeds the offer of the competition and which at the same time ensures the profitability of the company.

Organisations, searching for optimal business models for sustainable growth and development, take up strategic challenges based on the assumptions of sustainable development and sustainable business (Bossink, 2012; Cohen, 2011; Muller-Christ, 2011; Sharma and Ruud, 2003). This leads to long-term business continuity in line with all stakeholder groups. The way of conducting business activity is completely different nowadays, and in the era of unlimited access to information and knowledge there is a great possibility and speed of verification of the company's image and reputation on the market. Hence, the concept of a flexible and/or agile enterprise that can be used to build the company's longterm value is becoming increasingly important.

This business model contributes to generation of revenues by the company, but in relation to the value created within the company, as well as its place in a chain of values of the industry in which it operates (Fisken and Rutherford, 2002). In other words, the business model shows how the company generates revenues in relation to the value chain structure and its place in the industry value chain. It allows answering the question of who the client of the organisation is, what value he/she expects from the organisation, as well as how this value will be provided, and what the costs and revenues of the conducted business activity are (Cyfert and Krzakiewicz, 2011).

The key to success in business is therefore identifying and satisfying the needs and preferences of buyers by the company. Under the conditions of fierce competition, it is not enough to just declare a focus on the client by the company, but it is necessary to correctly understand the essence of the market orientation,

Business model maturity in management theory and practice - defining from an expert perspective 
and, first of all, to actually apply it in daily operation (Mazurek-Łopacińska, 2002). This is related to a method of company operation on the market that makes it possible to offer buyers products that are desired by them and which they searched for. The company, within the framework of its market activities, should offer buyers a product, which supported by promotion, delivered through the appropriate distribution channels and offered at a right price, will gain the buyer's acceptance. On the other hand, it should be borne in mind that the condition of functioning of every company, whether in terms of duration or development, is to have products in the range which will ensure adequate profitability. Its achievement is conditioned by obtaining such efficiency which makes the company more flexible, agile, smart, practised or trained.

Achieving the sustainability of economic activity comes about by following a coherent strategy of maximizing the value brought by a company operating for a long time, while optimizing the results achieved in the short and medium term. Successful achievement of this is due to many factors, including the quest for vigilance, endurance and resilience. This strategy requires keeping wellmaintained assets, continually introducing innovative products and services, and holding a good reputation among customers, employees, distributors, suppliers, authorities and other stakeholders investing in the company (Kotler and Caslione, 2009).

People, objectives, engineering, technology, and structure are the main components of any organisation, and are related and interact with each other. People are not only the foundation of any organisation, but they themselves are its material and the sense of its existence. The behaviour of people in the organisation should be characterized by the purposefulness of actions within which resources for its development are efficiently and effectively used with simultaneous responsibility towards the organisation itself and the environment. The assessment of the costs and benefits of an organisation's functioning can be made through the prism of building a system model, which is most often called the "operating model" or "business model". The term "business model" is used in a wide range of informal (non-uniform) and formal descriptions to represent the overall relationships of the activities of many or individual organisations, their parts or functions. It relates to capturing the most important resources, business processes, necessary elements contributing to creating, presenting and delivering a value offer to recipients, and to the ways of capturing the benefits of value exchange. An important problem in creating a business model is not only its presentation, but also grasping the functioning of the organisation according to the concept of sustainable development.

$x x$

PRZEMYSŁAW NIEWIADOMSKI 
In view of the authors of this paper, the mentioned qualities - through the creation of the organisation's abilities to predict, prepare, respond and adapt to current changes and sudden disruptions - make it possible for the companies not only to constantly develop, but also to use the emerging chances and opportunities.

According to the author of this study, it is unlikely that management practitioners will adopt a generally acceptable definition of the business model in the near future. In the context of the above, it is recommended to use terms that are meaningful in the context of organizational conditions and can be used consistently in conducted research, as in the case of this study. It is equally important that members of research teams, or a given organization, clearly understand the adopted definition and be able to define and explain the meaning of the adopted concept.

\section{Material and method}

Maturity is a term that began to appear in the organisation and management sciences in the 70s. It means a state of readiness for the implementation of certain activities. The maturity concept originates from both the quality management fields and the subject of good business practices (Auksztol and Chomuszko, 2012). The management theory and practice show that one definition is far from common acceptance. A methodological confusion has occurred in recent years that sometimes leads to conflicting opinions, and even disputes about what actually maturity is, and thus - what methods to use when testing it. It is this knowledge gap that was the foundation for undertaking the research presented in this chapter.

Maturity may be applied to individual elements of the organisation; then it has a partial dimension (partial maturity). Due to the complex nature of the entire organisation, which differs from each of the elements comprising it and at the same time contributing to its success, partial maturity extraction can be made in many different ways by using various criteria. This study assumes that maturity refers to the business model in a special way.

The presented studies were directed by striving for sorting out the issues of terminology and classification in the field of business model maturity. The term "maturity" that is crucial for this paper is defined as a set of standards that should be met in order to make the relationship between the obtained results and used competences (resources) as favourable as possible. The problem that determines the research activities was the lack of existence of determinants of the business

Business model maturity in management theory and practice - defining from an expert perspective 
model maturity. In the context of such an outlined problem, a question about the base for creating such a model was formulated.

In the context of the above, the fundamental research objective was to define the partial (functional) maturity that is representative of business model maturity. In the course of the implemented studies, efforts were made to obtain information on whether the mature business model is traditionally perceived through the prism of a long-term strategy and the consequent methods of operation or perhaps more as a paradigm, in which a focal point is the client and his/her individualised expectations. The research implementation scheme is illustrated in figure 1.

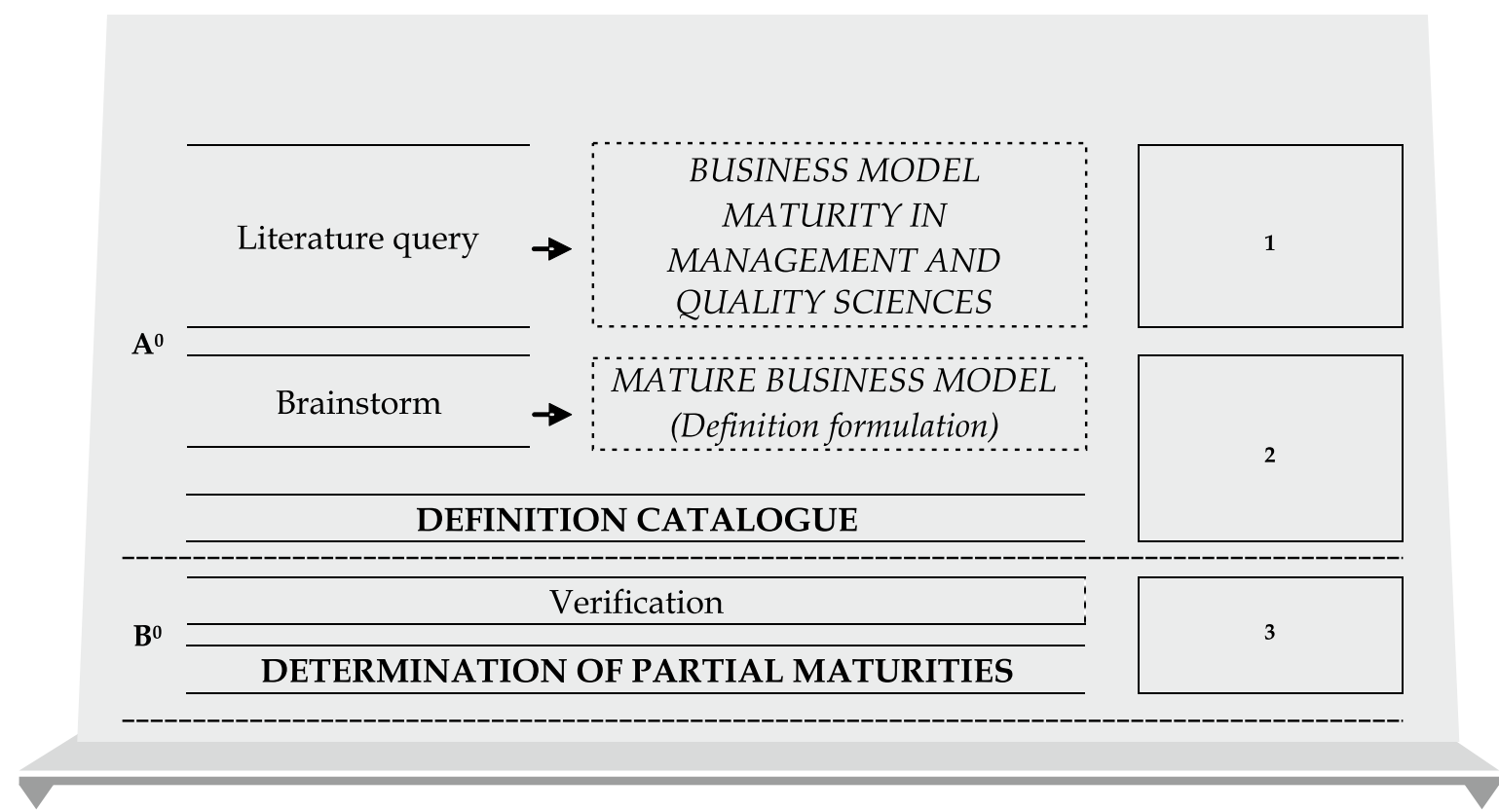

Figure 1. Research implementation scheme

Source: own study

By using the method for reconstruction and interpretation of the subject literature (among others, Teece, 2010; Baden-Fuller and Morgan, 2010; CasadesusMasanell and Ricart, 2010; Chesbrough, 2007; Howe, 2004; Kindström, 2010; Magretta, 2002; Morris, Schindehutte and Allen, 2005; Neely and Delbridge, 2007; Osterwalder and Pigneur, 2010; Wikström, Artto, Kujala and Söderlund, 2010; Joyce and Paquin, 2016; Osterwalder, Pigneur and Tucci, 2005) supported by the authors' own opinions and experience, Catalogue of descriptions referring to the 
general business model in the context of its maturity assessment was selected. The literature query was supported by a study among deliberately selected experts related to the agricultural machinery sector (table 1).

Table 1. Characteristics of experts

\begin{tabular}{|c|c|c|}
\hline Expert & Specialisation & [\%] \\
\hline $\begin{array}{l}\text { Owners of companies operating in } \\
\text { the agricultural machinery sector [6] }\end{array}$ & Organisation and management; owner supervision & 35.29 \\
\hline $\begin{array}{l}\text { Managers employed based on an } \\
\text { employment agreement } \\
\text { or contract [5] }\end{array}$ & $\begin{array}{l}\text { The management of the activity of subordinate } \\
\text { areas in order to obtain the determined business } \\
\text { efficiency }\end{array}$ & 29.41 \\
\hline $\begin{array}{c}\text { Director - Łukasiewicz Research } \\
\text { Network [1] }\end{array}$ & $\begin{array}{l}\text { Supervision over the execution of contracts } \\
\text { and the quality of research, correctness assessment } \\
\text { of using the research procedures and instructions, } \\
\text { verification of the research results }\end{array}$ & 5.88 \\
\hline $\begin{array}{l}\text { Vice Director - the Marshal Office of } \\
\text { the Wielkopolska Province [1] }\end{array}$ & $\begin{array}{l}\text { Development strategy for Wielkopolska and } \\
\text { provincial programme projects; active participation } \\
\text { in creating their execution conditions }\end{array}$ & 5.88 \\
\hline University representative [2] & $\begin{array}{l}\text { Management and Quality Sciences, including } \\
\text { strategic management oriented towards business } \\
\text { models and management strategies }\end{array}$ & 11.76 \\
\hline $\begin{array}{c}\text { President of the Management } \\
\text { Board [1] }\end{array}$ & $\begin{array}{c}\text { Development of investment plans, development } \\
\text { plans ensuring the implementation of strategic } \\
\text { objectives, including the provision of a constant } \\
\text { increase of the company while improving } \\
\text { profitability }\end{array}$ & 5.88 \\
\hline $\begin{array}{l}\text { Member of the Management } \\
\text { Board [1] }\end{array}$ & $\begin{array}{l}\text { The search for business synergies between } \\
\text { individual business lines }\end{array}$ & 5.88 \\
\hline
\end{tabular}

The choice of form for obtaining expert opinion determined the essence of the reliability of the results, the available time of research, costs and the degree of conformity of the experts. Expert opinions were obtained during the discussion being a form of an open, collective discussion of the problem.

Each of the 17 experts was tasked to formulate 1 definition of MBM (mature business model) in no more than 15 minutes and write it on a sheet of paper. 
As the form of this method is written, sheets were used that were circulated between all participants in the study; everyone had access to the saved content. In the end, this resulted in a catalogue of 17 definitions. After the completion of two stages, the assessment of the obtained results was summarized. All the above definitions were written down, similar ideas were grouped, own observations were added, which in perspective allowed compiling the final list of definitions.

The overall number of experts and the percentage composition of the group were associated with the complexity of the problem being solved, the reliability of assessments, and the expenditure on conducting the expertise. The size of the problem solved determined the need to involve field specialists in the expertise.

Constructiveness of thinking expressed by the ability of practical application of knowledge was adopted as the basic criterion for the selection of experts. An equally important feature of the expert is his/her independence. Conformism - defining submission in relation to the authorities - is, in fact, a common situation during the open discussions. Too much submission distorts the real view of the considered problem. The expert's level of knowledge in a given field was expressed by competence. It was determined on the basis of an expert's creative analysis, knowledge of the field, and understanding of problems. Expert competence was assessed on the basis of the competence coefficient, which expressed the dependence of the informativity coefficient [Ki] (knowledge of the given issue) and argumentation coefficient [KA]. The presented experts' characteristics sufficiently describe his/her suitability for expertise. Details are shown in table 2.

Table 2. Detailed characteristics of experts

\begin{tabular}{|c|c|c|c|c|c|c|c|c|c|c|c|c|}
\hline \multirow[b]{2}{*}{ Expert } & \multicolumn{5}{|c|}{ Age } & \multicolumn{3}{|c|}{ Education } & \multicolumn{4}{|c|}{ Organisation size } \\
\hline & 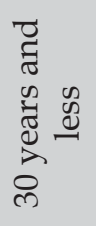 &  & 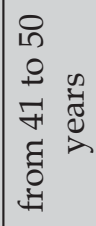 & 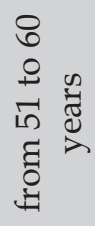 & $\begin{array}{l}8 \\
\varnothing \\
0 \\
0\end{array}$ &  &  &  & : & 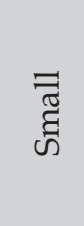 & 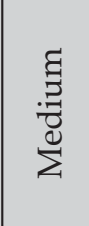 & $i_{00}^{\infty}$ \\
\hline Number of Experts & 0 & 7 & 6 & 1 & 3 & 16 & 0 & 1 & 0 & 2 & 11 & 4 \\
\hline [\%] of Experts & 0 & 41.2 & 35.3 & 5.9 & 17.6 & 94.1 & 0 & 5.9 & 0 & 11.8 & 64.7 & 23.5 \\
\hline Total [\%] & \multicolumn{5}{|c|}{100} & \multicolumn{3}{|c|}{100} & \multicolumn{4}{|c|}{100} \\
\hline
\end{tabular}

Source: own study 
The expert studies were targeted to the intellectual abilities of the entity without taking into account the entire group. Therefore, each study participant individually formulated a definition that in his/her opinion should represent business model maturity (individual brainstorming). The expert studies of phenomenological nature (based on experience) allowed identifying the opinions, feelings and associations that in the analysed case, resulted from a number of factors related to the business model maturity perception problem. In addition, they confirmed the sense and purpose of the next study implementation and provided interesting information on the language used by "industry experts" to describe the phenomena being the subject of the definition. The author believes that it allowed avoiding mistakes at the level of modelling the basic research. Undertaking the research was mandatory as it resulted also from the daily observation of "practice" run as part of the professional duties performed by the author.

\section{Study results}

The information needed for strategic management is to present data on future states, trends and development of external factors affecting the enterprise, including the analysis of opportunities, chances and threats. It is the opportunities that are conducive to achieving the company's goals using the resources available to it, especially since the improvement of the company is to some extent based on searching, capturing and creating opportunities for future development. The goal as an indicator in the field of opportunities is emphasized by S. Trzcieliński (2011), according to whom an opportunity is a situation conducive to the subject of the action in achieving the intended goal or desired effect that exists in the environment of this entity or is the postulated state of the features of this environment.

The opportunities often appear under the guise of problems or situations that seem to be not promising at first glance. What is noticeable when confronted with them depends on the perception of the involved person and on the business model adopted by the enterprise. Thus, enterprises should increasingly orient their resources and competences towards search for valuable opportunities, which, in the author's opinion, should highlight expert definitions of a mature business model.

The analysis shows that defining a mature business model is not an easy task; the term is ambiguous, although a common ground can be found for individual interpretations. It is the search and analysis of factors contributing

Business model maturity in management theory and practice - defining from an expert perspective 
to the effective operationalization of - possible to be used - opportunities, taking into account the owned resources and held competences. The definitions of a mature business model compiled in the paper are formulated through the prism of specific desiderata and an indication of the effects of their impact (table 3).

Table 3. Expert of mature business model definitions

\begin{tabular}{l|l|l|l|l|l|l}
\hline & & & \\
\hline
\end{tabular}




\begin{tabular}{|c|c|c|c|c|c|}
\hline $\begin{array}{l}\text { It is related to the way of creating the value for clients and } \\
\text { the opportunity created by the company, but the value is } \\
\text { created by the transformation of the owned resources in } \\
\text { a particular effect as a result of the execution of activities. }\end{array}$ & & & $X$ & $X$ & \\
\hline $\begin{array}{l}\text { It reflects the ideas, values and opportunities that must be } \\
\text { realised with the use of resources and competences that } \\
\text { the company has. }\end{array}$ & & & & $X$ & \\
\hline $\begin{array}{l}\text { It indicates a domain of the activity, in which the } \\
\text { company wants to be present. It describes what resources } \\
\text { the company needs to create products, while at the same } \\
\text { time, satisfying the individualised needs of the dynamic } \\
\text { environment. }\end{array}$ & $X$ & $X$ & & & $x$ \\
\hline $\begin{array}{l}\text { The vision reflecting the best way of using organisational } \\
\text { resources and competences realised by the ability to } \\
\text { quickly identify and use the opportunities emerging in } \\
\text { the environment. }\end{array}$ & $X$ & & & $X$ & \\
\hline $\begin{array}{l}\text { The model of operation taking into account the continuous } \\
\text { and dynamic process of provoking the opportunities } \\
\text { aimed at long-term development. }\end{array}$ & & & & $X$ & \\
\hline $\begin{array}{l}\text { The company development method presented with the } \\
\text { use of simple principles and rules created as a result of } \\
\text { operationalisation of potentially useful opportunities, } \\
\text { while taking into account the owned resources and } \\
\text { competences of the management personnel. }\end{array}$ & $X$ & & & $X$ & \\
\hline $\begin{array}{l}\text { The description of the desired state of the company in } \\
\text { the future, taking into account the available resources } \\
\text { and skills which represent the possibility of creating and } \\
\text { realising the opportunities before competitors do it. }\end{array}$ & $X$ & & & $X$ & \\
\hline $\begin{array}{l}\text { The model of operation strongly associated with the } \\
\text { identification of opportunities and creation of innovative } \\
\text { solutions posing a chance to take advantage of these } \\
\text { opportunities. It provides success and creates an added } \\
\text { value by the effective application of new ideas. }\end{array}$ & & & & $X$ & \\
\hline $\begin{array}{l}\text { It defines the configuration direction of the resources at } \\
\text { the disposal of the organisation in response to the impact } \\
\text { of both internal and external factors for the market } \\
\text { adaptation that affect the ability to increase the efficiency } \\
\text { of the company functioning. }\end{array}$ & $X$ & & & & \\
\hline
\end{tabular}

Business model maturity in management theory and practice - defining from 


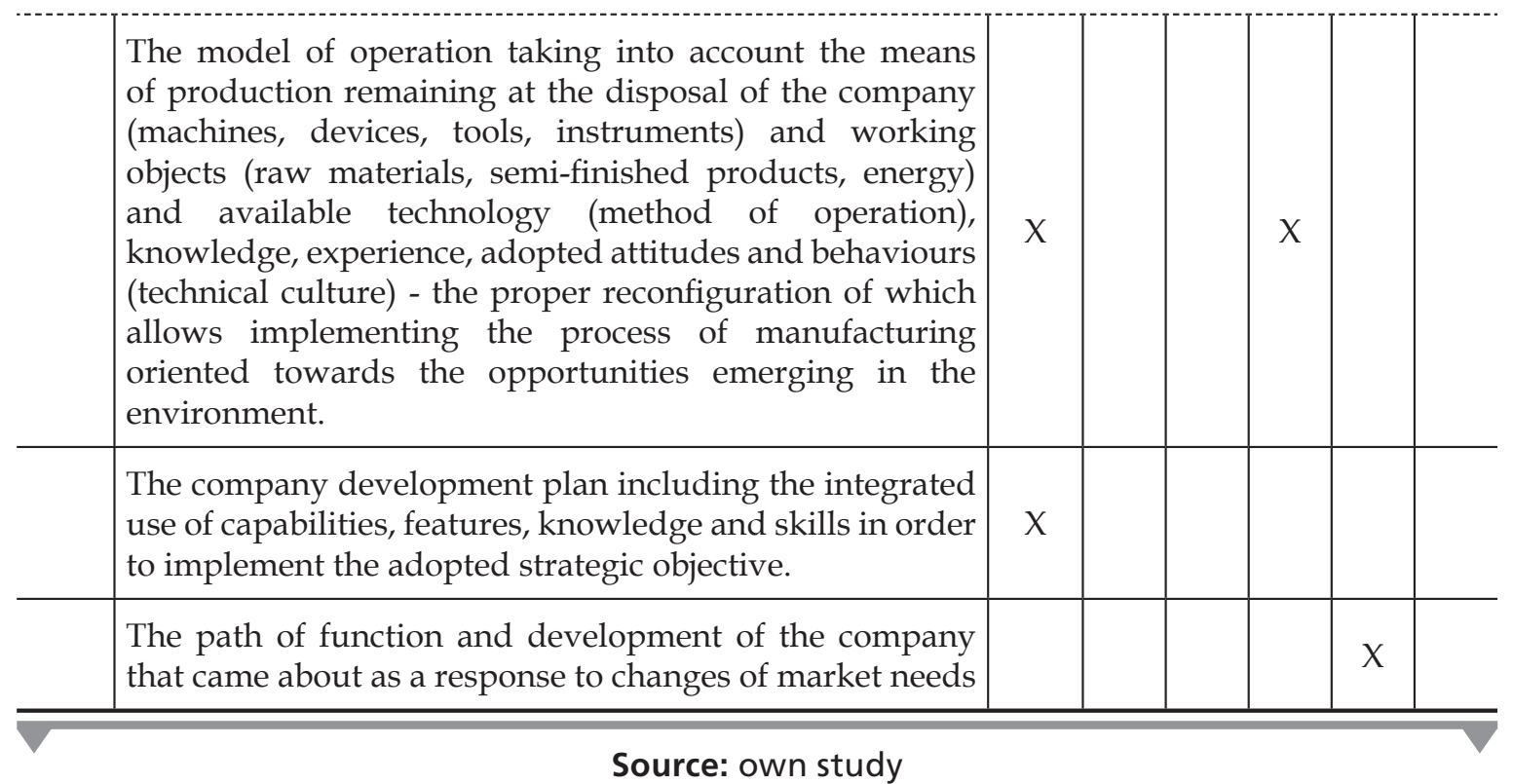

Theformulated definitions are closely linked to the opportunities (13 definitions; i.e. $82.35 \%$ ) that should be identified and applied by the companies. These are the opportunities that constitute situations conductive to achieving the company's objectives with the use of its available resources, especially that the company improvement involves, to a certain extent, finding, grasping and creating opportunities for development. In this sense, the information, which should present the data on future states, trends and development of external factors affecting the business model and analysis of own capabilities, opportunities and threats, is important. It requires building and putting into practice innovative business models within the framework of which the company will be able to use opportunity. However, in order to take advantage of such opportunities, beyond simple rules, production resources are required as well.

These and a number of other reasons initiate the undertaking by the author of intensive studies in the concept of a flexible and/or agile organization, since, as shown by the presented studies, these are the features that determine stable functioning of the modern company. Moreover, they are the main condition for its development. The research results will be presented in the form of further studies.

Business models that are oriented towards taking advantage of opportunity realise a formal and systematic approach to the management of the company that is directed towards the achievement of the objective - that is to maximise the profit through optimal use of available resources. The opportunity operation 
may come to closure when its use of various satisfaction levels corresponds to the level of achieving the objectives and the opportunity ends (Trzcieliński, 2011). In this sense, the opportunity value is understood as a benefit that the company may obtain as a result of using the arising opportunity. Herein, the greater the opportunity value, the higher is the profit per unit of the manufactured product. Assuming that the opportunity value is a value dependent on demand and supply as occurring in the manufacturer's environment, the greatest profit is brought by the opportunities associated with the implementation of a product constituting a niche, with a small market share. The revenues obtained from the sale of these products cover the costs with a surplus, which make their profitability high, and the saved funds can supply other products in the manufacturer's portfolio.

The opportunity value, in a sense, is determined by the ability to perceive the market opportunities that are given to manufacturers by the possibly fast implementation of the niche product providing the above-average margins.

In the context of the above, the companies should increasingly deepen and engage their resources, skills and competences in the development and introduction of new products constituting the market niches. In order to increase the probability of success, the company must adapt its business model to the changing environment. In the context of the above, it is not surprising that for some time (in recent years), organisational flexibility and agility have become the subject of particular attention in modern business modelling.

An increase in the strategic importance of managing the company's flexibility or agility is reflected in the literature when it meets various general formulas of defining these concepts.

\section{Discussion}

According to experts invited to participate in the study, a mature business model is closely linked to an opportunity. Enterprises optimally try to introduce resources that create possibilities to take advantage of the opportunities they have to face. This view is shared among the authors of the presented definitions, according to which it is the opportunities that are conducive to achieving the company's goals using the resources available to it, especially since the improvement of the company is to some extent based on searching, capturing and creating opportunities for future development (Krupski, 2005). One of the methods proposed in this regard is setting goals, because when the manufacturer has a devised target, s/he opens to a broader perspective to "see" the possibilities and opportunities that s/he could not

Business model maturity in management theory and practice - defining from an expert perspective 
identify before. T. Pszczołowski (1978) treats an opportunity as a necessary condition for behaviour leading to the desired effect or intended purpose. An interesting definition of opportunity is provided by R. Krupski (2005), who notes that an opportunity for an enterprise is an event (e.g. the collapse of its competitor) or a combination of various circumstances (e.g. the creation of a market niche) of an economic nature, creating the possibility of obtaining additional benefits, as well as tangible and/or intangible values. The author emphasizes that the opportunities are closely related to the moment and time period. They appear, last for some time and disappear both in the closer, but also distant surroundings and inside the enterprise. For an enterprise, an opportunity can be defined as an event or an emerging combination of various circumstances of an economic nature or effect, creating opportunities for additional benefits. It can be assumed that the strategies implemented in reality by enterprises are in fact a kind of combination of plan and opportunity orientation.

The conducted expert talks and an in-depth query of the subject literature point to the identification of the mature business model with:

- the ability to categorize situations as favourable and unfavourable (Sajdak 2014),

- the ability to search for technological niches (Amin 1994; Autio 1997; Carnabuci, Bruggeman 2009; Hirst, Zeitlin 2006),

- the ability to reconfigure available technological resources, i.e. means of production, work objects and available technology (Eisenhardt, Martin 2000; Teece 2012, Christensen 1995; Garrouste, Saussier 2005).

Assuming the above as an interpretation in this study, it was assumed that: a mature business model should be scaled towards opportunities understood as situations in which taking a decision by a manufacturer is associated, in the near future, with a high probability of obtaining significant benefits in the form of profit. It usually concerns new ideas, solutions and directions of activity; it is the basis for imitating or introducing innovations in the organization of production.

Taking advantage of the opportunity that appears in the environment results from the manufacturer's ability to reconfigure the available means of production (machinery, equipment, tools, instruments), work items (raw materials, materials, semi-finished products, energy) and available technology (work method), as well as knowledge (including engineering expertise), personal predispositions of executive employees, as well as acquired experience, adopted attitudes and behaviours (technical culture). While speaking about resource reconfiguration - in the context of the use of emerging opportunities - attention is drawn to 
lean, flexible and agile production processes, which are in fact derived from their competences.

A mature business model is the result of systematic monitoring of the environment conducted by the company. Immediate assessment is advisable owing to the temporary limitation of the opportunity existence because it is not known how long the opportunity will last. After identifying the actions necessary to seize opportunities, their implementation should be immediately planned, including the provision of financial resources for the use of the opportunities. A view is formulated that the more positive the assessment of the opportunity, the sooner financial resources should be made available. In the implementation of activities aimed at the actual use of opportunities, learning is an important factor affecting the success of these activities, because the use of opportunities is in fact a game without established rules that are only discovered, verified and used by the participants of the organization. It can be assumed that the ability to thoroughly understand the conditions in which an opportunity was noticed is crucial; also its consistent use in business modelling is of key importance.

\section{Conclusion}

Phenomenological, expert research enabled to identify opinions, feelings and associations that were evoked in the analysed case by a number of factors related to the problem of perception of a mature business model (recognition by science of inventive creation). The presented publication articulated the desiderata - outlined by field experts - of the mature business model definition. The merits of the axiom of the business model (query of the literature) were made apparent and on this basis a list of definitions constituting the research model was compiled, which will be verified among enterprises in the next stage of the research; the research will be presented in a separate publication. This will enable to recognize whether selected representatives of enterprises (management practitioners) understand the maturity of the business model in the same way as the field experts invited to research? In other words, it will provide information as to whether the definitions resulting from the expert discussion (as illustrated in this research paper) coincide with the direction of perception of a mature business model by the surveyed companies ( survey in the form of an expert interview ). In sum, the exploratory studies presented in the paper on the one hand confirmed the sense and purposefulness of carrying out the next stage, while on the other, they provided interesting information about the language used by industry experts to describe the processes being the definition subject. 
The following theoretical and design arguments were obtained:

1. Experts associated with the Polish agricultural machinery sector understand the maturity of the business model in a similar manner to selected science representatives (literature researchers).

2. In the experts' view, mature business models should be oriented on resources, product, customer and opportunity (agility, flexibility).

3. By using the recognition methods through invention, it is possible to formulate descriptions postulating about the business model maturity.

4. The surveyed experts demonstrate a high level of professional knowledge and the ability to define selected categories in the field of management and quality sciences. In view of the above, sticking to all the rules of methodological rigour (including selection of experts), there are premises for conducting research using heuristic methods.

5. The definitions resulting from the expert discussion reflect distinctive descriptions for the business model, and the level of concretization indicates its maturity.

6. In the experts' view a business model, in which the point of reference is an opportunity and the flexibility which implies the possibility of its realization is crucial.

7. The process of transforming enterprises into a business model oriented at resources, product, customer and opportunity (agility, flexibility) shows their tendency towards maturity.

Summing up, the presented publication articulated the level of substrates outlined by field experts that determine the business model maturity, which means that the fundamental goal of the paper was achieved. The substance of its axiom was exposed, the areas determining maturity were nominated, and the research model was compiled, which in the perspective of further research will allow the recognition of the level in the perception and concretization of selected maturity indicators in business modelling.

Despite the undeniable popularity of the concept of maturity in the business environment and the constantly growing research interest in this issue, it turns out that there are many areas that need to be solved in the near future. In the author's view, one of the basic research needs is to develop a universal tool that would allow assessing the level of maturity of the business model. The requirement for such an assessment tool is often mentioned in the environment of agricultural machinery manufacturers. In order to authenticate the existing research gap, the author of this study conducted a series of conversations with managers representing the indicated sector.

PRZEMYSŁAW NIEWIADOMSKI 


\section{Summary}

Business model maturity in management theory and practice defining from an expert perspective

Since many researchers and managers think about the essence, creation mechanisms and limits of the manufacturing model maturity, at this point, the author raises the question related to this issue: what dimensions (descriptions and desiderata) should be considered when conceptualizing this idea? The formulated question became a starting point and a point of conducting a creative synthesis, based, on the one hand, on a detailed analysis of the problem theory, and on the other hand - on the author's own research. The above question and belief related to the existence of economic demand for results of application nature were the main inspiration to undertake research whose main purpose is to recognize: how the maturity of the business model is understood by selected experts operating in the Polish agricultural machinery sector?

Keywords: Maturity, business model, opportunity, mature business model.

\section{Streszczenie}

Dojrzałość modelu biznesu w teorii i praktyce zarządzania definiowanie z perspektywy eksperckiej

Jako że wielu badaczy i zarządzających zastanawia się nad istotą, mechanizmami kreowaniaigranicami dojrzałości modelubiznesu, w tym miejscu autor stawia - związane z tym zagadnieniem pytanie:jakie wymiary (deskrypty i dezyderaty)należy uwzględnić dokonując konceptualizacji tego pojęcia? Sformułowane pytanie stało się punktem wyjścia i przeprowadzenia twórczej syntezy opartej z jednej strony na szczegółowej analizie teorii problemu, a z drugiej na badaniach własnych autora. Powyższe pytanie oraz przekonanie o występowaniu gospodarczego zapotrzebowania na wyniki o charakterze aplikacyjnym stanowiły główną inspirację do podjęcia badań, których zasadniczym celem jest rozpoznanie jak dojrzałość modelu biznesu rozumieją wybrani eksperci działający w polskim sektorze maszyn rolniczych?

Słowa

kluczowe: Dojrzatość, model biznesu, okazja, dojrzaty model biznesu. 


\section{JEL}

\section{Classification: E20, I12, E24}

\section{References:}

1. Afuah, A., Tucci, Ch. (2003). Biznes internetowy. Strategie i modele [Internet business. Strategies and models], Oficyna Ekonomiczna, Kraków.

2. Amin, A. (ed.) (1994), Post-Fordism. A Reader, Blackwell Publishers, Oxford, Malden.

3. Auksztol, J., Chomuszko, M. (2012). Modelowanie organizacji procesowej [Modelling of the process organisation], PWE, Warszawa.

4. Autio, E. (1997). New Technology - Based Firms in Innovation Networks Symplectic and Generative Impacts, Research Policy, vol. 26, pp. 263-281.

5. Baden-Fuller, Ch., Morgan, M.S. (2010). Business models as models, Long Range Planning, 43, pp. 156-171.

6. Bossink, B. (2012). Eco-innovation and Sustainability Management, Routledge Taylor \& Francis Group, New York and London.

7. Carnabuci, J., Bruggeman, J. (2009). Knowledge Specialization, Knowledge Brokerage and the Uneven Growth of Technology Domains, Social Forces, vol. 88, no. 2, pp. 607-641.

8. Casadesus-Masanell, R., Ricart, J.E. (2010). From strategy to business models and onto tactics, Long Range Planning, 43, pp. 195-215.

9. Chan Kim, W., Mauborgne, R. (2006). Strategia Btękitnego Oceanu. Jak stworzyć wolna przestrzeń rynkowa i sprawić by konkurencja stata się nieistotna [Blue Ocean Strategy. How to create a free market space and make competition become irrelevant], Wydawnictwo MT Biznes, Warszawa.

10. Chesbrough, H. (2007). Business model innovation it's not just about technology anymore, Strategy \& Leadership, 35, 6, pp. 12-17.

11. Christensen, J. F. (1995). Asset Profiles for Technological Innovation, Research Policy, vol. 24, pp. 727-745.

12. Cohen, S. (2011). Sustainability Management, Columbia University Press, New York.

13. Cyfert, S., Krzakiewicz, K. (2011). Wykorzystanie koncepcji modeli biznesu $w$ zasobowej teorii firmy [The use of the business model concept in the company resource theory]. In: Krupski, R. (ed.), Rozwój szkoty zasobowej zarzadzania strategicznego [Development of a resource school of strategic management], Wałbrzyska Wyższa, Szkoła Zarządzania i Przedsiębiorczości, Wałbrzych, pp. 99-107.

14. Ehiraj, S., Guler, I., Singh, H. (2000). E-Business Models: Value Creation and Competitive Advantage, The Warton School, Philadelphia.

15. Fisken, J., Rutherford, J. (2002). Business Models and Investments. Trends in the Biotechnology Industry in Europe, Journal of Commercial Biotechnology, Vol. 8(3), pp. 191-199. 
16. Garrouste, P., Saussier, S. (2005). Looking for a Theory of the firm: Future Challenges, Journal of Economics Behavior \& Organization, vol. 58, pp. 178199.

17. Hamel, G. (2002). Leading the revolution, Harvard Business School Press, Boston.

18. Hirst, P., Zeitlin, J. (2006). Flexible Specialization versus Post-Fordism: Theory, Evidence and Policy Implications. In: Beynon H., Nichols T. (eds.), The Fordism of Ford and Modern Management, Elgar, Cheltenham.

19. Howe, P.E. (2004). Business models. CPA Journal, vol. 74.

20. Joyce, A., Paquin, R.L. (2016). The Triple Layered Business Model Canvas: A Tool to Design More Sustainable Business Models, Journal of Cleaner Production, 135, pp. 1474-1486.

21. Kindström, D. (2010). Towards a service-based business model - Key aspects for future competitive advantage, European Management Journal, 28, 6, pp. 479-490.

22. Kotler, P., Caslione, J.A. (2009). Chaos, zarzadzanie $i$ marketing w erze turbulencji [Chaos, management and marketing in the era of turbulence], MT Biznes, Warszawa.

23. Krupski, R. (2005). Zarzadzanie przedsiębiorstwem w turbulentnym otoczeniu. $\mathrm{Ku}$ superelastycznej organizacji [Company management in the turbulent environment. Towards superflexible organisation], PWE, Warszawa.

24. Magretta, J. (2002). Why Business Models Matter, Harvard Business Review, 80, 5, pp. 86-92.

25. Mazurek - Łopacińska, K. (2002). Orientacja na klienta w przedsiębiorstwie [Client-orientation in the company], PWE, Warszawa:

26. Morris, M., Schindehutte, M. and Allen, J. (2005). The entrepreneur's business model: Toward a unified perspective, Journal of Business Research, 58, pp. 726-735.

27. Muller-Christ, G. (2011). Sustainable Management, Springer, Berlin Heidelberg.

28. Neely, A., Delbridge, R. (2007). Effective Business Models: What do They Mean for Whitehall? Sunningdale Institute.

29. Nogalski, B., Niewiadomski, P. (2018). Metoda oceny potencjału dynamizującego kompozycje modelu biznesu zorientowanego na wspólne innowacje - eksploracja $\mathrm{w}$ sektorze maszyn rolniczych [A method of assessing the potential of dynamizing compositions of a business model oriented at joint innovations - exploration in the agricultural machinery sector], Zeszyty Naukowe Politechniki Ślaskiej: Organizacja i Zarzadzanie, from 108, 127, pp. 175-190.

30. Nogalski, B., Niewiadomsk,i P. Szpitter, A. (2017). Elastyczne modele biznesu przedsiębiorstw produkcyjnych sektora maszyn rolniczych - próba oceny ich implementacji [Flexible business models of manufacturing companies in the 
agricultural machinery sector - an attempt to evaluate their implementation], In: Rokita, J. (ed.), Strategiczne zarzadzanie organizacjami - problemy badawcze $i$ praktyczne [Strategic management of organisations - research and practical problems], Wydawnictwo Górnośląskiej Wyższej Szkoły Handlowej im. Wojciecha Korfantego, Katowice, pp. 125-148.

31. Nogalski, B., Niewiadomski, P., Szpitter, A. (2018a). Creativity in the Aspect of Composition of Business Models of Manufacturers from the Agricultural Machines Sector: An Attempt to Assess the Significance of the Requirements, Journal of Management and Financial Sciences JMFS, XI, 31, pp. 9-26.

32. Nogalski, B., Niewiadomski, P., Szpitter, A. (2018b). Reconnaissance of the Ability to Profile a Business Model Focused on Market Niches - Expert Self-assessment in the Machine Sector, Entrepreneurship and ManagementPrzedsiębiorczość i Zarządzanie, XIX, 6, I, pp. 41-52.

33. Osterwalder, A., Pigneur, Y. and Tucci, C.L. (2005). Clarifying Business Models: Origins, Present, and Future of The Concept, Communications of the Association for Information Systems, 15, pp. 1-25.

34. Osterwalder, A., Pigneur, Y. (2010). Business Model Generation, John Wiley \& Sons, Inc., New Jersey.

35. Pszczołowski, T. (1978). Mała encyklopedia prakseologii i teorii organizacji [Little encyclopedia of praxeology and organization theory], Ossolineum, Wrocław.

36. Sajdak, M. (2014). Zwinność przedsiębiorstwa jako koncepcja zarządzania między stabilnościa a chaosem [Business agility as a concept of management between stability and chaos]. In: Romanowska, M., Cygler, J. (eds.), Granice zarzadzania [Limits of management], Oficyna Wydawnicza Szkoła Główna Handlowa w Warszawie, Warszawa.

37. Sharma, S., Ruud, A. (2003). On the path to sustainability: Integrating social dimensions into the research and practice of environmental management, Business Strategy and the Environment, 12, pp. 205-214.

38. Teece, D. J., (2012). Dynamic Capabilities: Routines versus Entrepreneurial Action, Journal of Management Studies, Vol. 49, Issue 8.

39. Teece, D.J. (2010). Business models, business strategy and innovation, Long Range Planning, 43, pp. 172-194.

40. Trzcieliński, S. (2011). Przedsiębiorstwo zwinne [Agile company], Wydawnictwo Politechniki Poznańskiej, Poznań.

41. Wikström, K., Artto, K., Kujala, J. and Söderlund, J. (2010). Business models in project business, International Journal of Project Management, 28, pp. 832-841. 